\title{
SYNTHESIS AND EVALUATION OF ETHYL (4-(N-(THIAZOL-2-YL) SULFAMOYL) PHENYL)CARBAMATE (TSPC) AS A CORROSION INHIBITOR FOR MILD STEEL IN 0.1M HCL
}

\author{
A. M. El-Shamy ${ }^{*}$, M. F. Shehata ${ }^{1}$, Samir T. Gaballah ${ }^{2}$ and Eman A. Elhefny ${ }^{2}$ \\ ${ }^{1}$ Physical Chemistry Department, Electrochemistry and Corrosion Lab., National Research Centre, Dokki, \\ Cairo, Egypt, 12622 \\ ${ }^{2}$ Photochemistry Department, National Research Centre, Dokki, Cairo, Egypt, 12622 \\ *Corresponding author elshamy10@yahoo.com
}

\begin{abstract}
Laboratory synthesized ethyl (4-( $\mathrm{N}$-(thiazol-2-yl)sulfamoyl)phenyl)carbamate (TSPC), characterized by ${ }^{1} \mathrm{H}$ NMR spectroscopy, was evaluated as corrosion inhibitor of mild steel in $0.1 \mathrm{M} \mathrm{HCl}$ using electrochemical techniques. Open circuit potential, potentiodynamic polarization and impedance spectroscopy were used to evaluate the inhibition efficiency of (TSPC) at various concentrations. The obtained electrochemical data indicated that (TSPC) acts as moderate corrosion inhibitor for mild steel in acidic media. It is found that the inhibition efficiency increases with the concentration of the inhibitor till 400ppm. The adsorption isotherm involving physisorption of (TSPC) at room temperature and the experimental data complied to the Langmuir adsorption isotherms and the negative values of the Gibb's free energy of adsorption obtained suggested that inhibitor molecules have been spontaneously adsorbed onto the mild steel surface.
\end{abstract}

Key words: Acid corrosion inhibitor; Mild steel; Organic synthesis.

\section{Council for Innovative Research}

Peer Review Research Publishing System

Journal: Journal of Advances in Chemistry

Vol. 11, No. 2

editorjaconline@gmail.com

www.cirjac.com 


\section{1- INTRODUCTION}

Acid cleaning is the more convenient and effective method for removal of the undesired scales and rust. $\mathrm{HCl}$ is usually the most widely used as industrial acids, cleaning and pickling acids. It is well known that the hydrochloric acid solutions are considered as very corrosive on the mild steel surfaces. Generally corrosion inhibitors have been used in these processes to protect metal dissolution to secure the metal against an acid attack [1]. There are many papers and researches have been studied and discussed the effect of synthesized organic inhibitor in different acidic media to be used as commercial corrosion inhibitors [2-6]. The mode of action of organic compounds is depending on the presence of polar groups which including nitrogen, sulfur and/or oxygen atoms. The heterocyclic compounds with polar functional groups and conjugated double bonds are expected to give high efficiency of corrosion protection so it is could be used as good corrosion inhibitors [7-9]. Recently the world takes the action towards the using of environmentally corrosion inhibitors instead of the toxic organic compounds to be used as commercially corrosion inhibitors. The corrosion inhibition process is appears as a result of formation of metal inhibitor complex by adsorption of organic molecules on the metal surface [10]. On the other hand the adsorption process of the organic molecules on the metal surface is attributed with the formation of co-ordination bond between the lone pair of electrons of nitrogen atom and/or the m-electron cloud and the metal surface. The formed bond between the organic compound and the steel surface form thin film from the organic molecule on the metal surface which, reduces the corrosive attack of metal in acidic media [11]. The efficiency of corrosion protection and its mechanism of their action are affected by many factors depending on the metal, the medium and the structure of the inhibitor. The higher inhibition efficiency of the corrosion inhibitor is back to its adsorption ability which is strengthen by the presence of $\mathrm{C}=\mathrm{N}$ - group $[12,13]$. The organic inhibitor is considered efficient when it rich with polar group and/or $\pi$-electrons which blocks the metal surface and thus do not permit the corrosion process to take place $[14,15]$. In this work the inhibiting action of (TSPC) on the corrosion of mild steel in $0.1 \mathrm{M} \mathrm{HCl}$ solution has been investigated.

\section{2- MATERIALS AND METHODS}

\subsection{ELECTROCHEMICAL CORROSION TESTS}

Mild steel $(\mathrm{C}=0.15 \%, \mathrm{Si}=0.08 \%, \mathrm{~S}=0.025 \%, \mathrm{P}=0.025 \%$ and $\mathrm{Mn}=1.02 \%)$ encapsulated in a Teflon holder with the exposed area of $0.785 \mathrm{~cm}^{2}$ was used as the working electrode (WE). The surface was abraded successively by emery papers of different grades, i.e. 150, 320, 400 and 600 and finely polished with a 2400 polishing paper to obtain uniform mirror like finish, degreased with acetone and washed with distilled water before experiment. Platinum wire and dip type saturated calomel electrodes were used as counter and reference electrodes, respectively. Corrosion inhibitor solutions of concentration 100, 200,300,400, 500 and 600 ppm were prepared in analytical grade chemical reagents $0.1 \mathrm{M} \mathrm{HCl}$ using distilled water. For each experiment, a freshly prepared solution was used.

\subsection{WEIGHT LOSS MEASUREMENTS}

JA $1003 \mathrm{~A}$ electronic weighing balance with the accuracy of \pm 0.005 is used to weight the dried cleaned coupons before and after immersion into solutions of $0.1 \mathrm{M} \mathrm{HCl}$. Tests were conducted with different concentrations of inhibitor. At the end of the tests, the specimens were carefully washed in absolute ethanol having used nitric acid to quench further corrosion from taking place, and then reweighed. Triplicate experiments were performed in each case and the mean values reported.

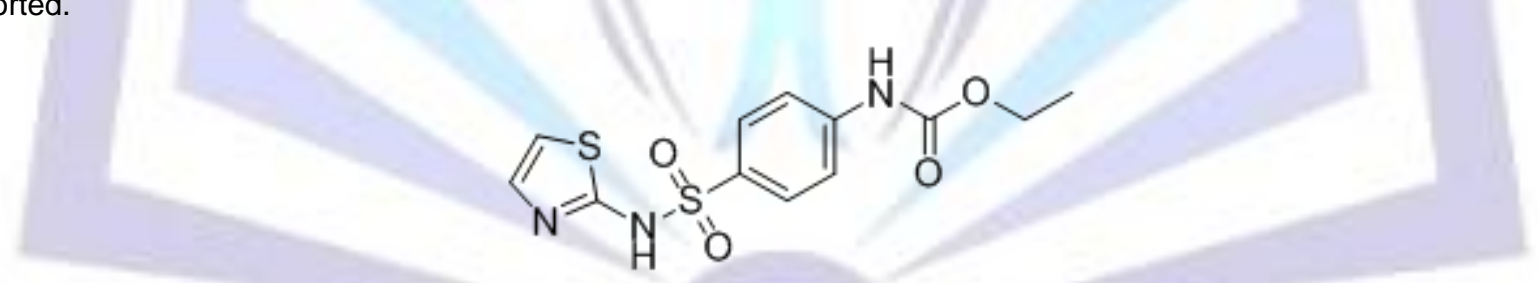

Figure (1) Chemical structure of (TSPC) corrosion inhibitor

\subsection{SYNTHESIS OF ETHYL (4-(N-(THIAZOL-2-YL)SULFAMOYL)PHENYL) CARBAMATE (TSPC)}

Our title compound, ethyl (4-(N-(thiazol-2-yl) sulfamoyl) phenyl) carbamate (TSPC), was synthesized in our laboratory as shown in Scheme (1) using modified methods reported in the literature starting with aniline. As a start point in our synthetic strategy, the amino group of aniline was first protected using the traditional method employing acetic anhydride/glacial acetic acid/sodium acetate (anhydrous) as a protecting reagent. The reaction was performed at ambient temperature for 1 h. The produced N-phenylacetamide (2) was converted to 4-acetamidobenzene-1-sulfonyl chloride $(3)$ [16,17] upon treating the former precursor with neat chlorosulfonic acid and heating at $60{ }^{\circ} \mathrm{C}$ with stirring for $1 \mathrm{~h}$ in $89 \%$ yield. The directionality of the sulfonyl chloride group of $\mathbf{3}$ was based on a regioselective electrophilic aromatic substitution. The key intermediate $\mathrm{N}$-(4-(N-(thiazol-2-yl)sulfamoyl)phenyl) acetamide (4) was formed by reacting 3 with 2-aminothiazole in dry dichoromethane at room temperature with stirring for 30-60 m [18]. To remove the acetyl group protection, compound 4 was treated with aqueous solution of potassium hydroxide in methanol at $65^{\circ} \mathrm{C}$ overnight to afford 4 -amino- $\mathrm{N}$-(thiazol-2-yl) benzene sulfonamide (5) in $75 \%$ yield [19]. Finally, 5 was reacted with ethyl chloroformate in dry acetone in presence of dry potassium carbonate at reflux for $8 \mathrm{~h}$ to afford the title compound as pale yellow solid product in $89 \%$ yield. 
<smiles>Nc1ccccc1</smiles>

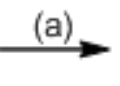<smiles>CC(=O)Nc1ccccc1</smiles>

2 (b)<smiles>CC(=O)Nc1ccc(S(=O)(=O)Cl)cc1</smiles>

3<smiles>CC(=O)Nc1ccc(S(=O)(=O)Nc2nccs2)cc1</smiles>

4<smiles>Nc1ccc(S(=O)(=O)Nc2nccs2)cc1</smiles>

5

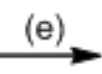<smiles>CCOC(=O)Nc1ccc(S(=O)(=O)Nc2nccs2)cc1</smiles>

Scheme 1: Synthesis of TSPC. Reagents and conditions: (a) acetic anhydride, acetic acid, $\mathrm{CH}_{3} \mathrm{COONa}$, stirring, rt, overnight; (b) chlorosulfonic acid, $60 \mathrm{oC}, 30-60 \mathrm{~m}$; (c) 2-aminothiazole, $\mathrm{CH}_{2} \mathrm{Cl}_{2}$, rt, $30 \mathrm{~m}$; (d) $\mathrm{KOH} / \mathrm{MeOH}, 65^{\circ} \mathrm{C}$; (e) ethyl chloroformate, $\mathrm{K}_{2} \mathrm{CO}_{3}$, acetone, reflux, $8 \mathrm{~h}$.

The structure of TSPC was confirmed by ${ }^{1} \mathrm{H},{ }^{13} \mathrm{C}, \mathrm{COSY}, \mathrm{HSBC}$, and HMBC NMR spectroscopies, mass spectrometry, and microanalysis. The methyl protons appeared as a triplet in ${ }^{1} \mathrm{H}$ NMR spectrum (d $\left.1.24 \mathrm{ppm}\right)$ and the $\mathrm{CH}_{2}$ protons of the ethyl group appeared as quartet at $\square \square 4.14 \mathrm{ppm}$. The correlation between the aromatic protons of the thiazole ring and the phenyl protons was confirmed by the cross peaks of the 2D COSY spectrum. However, the peaks appeared at $\square 7.7$ ppm $(\mathrm{d}, \mathrm{J}=8.8 \mathrm{~Hz})$ and $\square \square 7.57 \mathrm{ppm}(\mathrm{d}, \mathrm{J}=8.8 \mathrm{~Hz})$ are correlated and was assigned to the two phenyl protons adjacent to the sulfonamidic and carbamate groups, respectively. The cross peaks appeared at $\square \square 7.21 \mathrm{ppm}(\mathrm{d}, \mathrm{J}=4.5 \mathrm{~Hz})$, and $\square 6.77$ ppm ( $\mathrm{d}, \mathrm{J}=4.5 \mathrm{~Hz})$ are correlated and assigned to the thiazole ring protons.

The HMBC spectrum helped to observe three bond couplings between the carbamate carbonyl carbon and neighboring methylene and phenyl protons. In HMBC spectrum, two cross peaks appeared due to the interaction of methylene protons and phenyl protons with carbonyl carbon. The cross peak at $\square(153.3,4.14) \mathrm{ppm}$ was assigned to the interaction of carbonyl carbon with methylene proton. Whereas the cross peak at $\square \square(153.3,7.57)$ ppm was assigned to the interaction of carbonyl carbon with the phenyl protons adjacent to the carbamate group.

All chemicals were purchased from common commercial suppliers and used without further purification unless otherwise stated. Melting points were determined in open capillaries on a Gallenkamp melting point apparatus and are uncorrected. ${ }^{1} \mathrm{H}$ and ${ }^{13} \mathrm{C}$ NMR spectra were recorded on a Brucker Spectrometer, respectively, at 600 and $150.94 \mathrm{MHz}$ using DMSO-d as solvent and as a self-reference at $(\square \square 2.49$ ppm. Mass spectra were recorded on a Finnigan mat. SSQ-7000 GCMS spectrometer. Microanalyses were performed at the Microanalytical Center at Cairo University and their results were found to be in good agreement with calculated values $( \pm 0.2 \%)$. Reaction progress and compounds purity were checked by thinlayer chromatography (Merck $60 \mathrm{~F}_{245}$ aluminum sheets; hexane/ethyl acetate, 2:1) and visualized by UV light (254 nm).

To a solution of $5(5.1 \mathrm{~g}, 20 \mathrm{mmol})$ in acetone $(50 \mathrm{~mL})$ was added potassium carbonate $(5.52 \mathrm{~g}, 40 \mathrm{mmol})$ and the reaction was refluxed for $1 \mathrm{~h}$ with stirring. Ethyl chloroformate $(2.6 \mathrm{~mL}, 24 \mathrm{mmol})$ was added and the reaction mixture was refluxed with stirring for another 6-7 h. The mixture was concentrated under reduced pressure and the residue obtained was poured onto ice-water and stirred for $15 \mathrm{~m}$. The formed solid was collected by filtration on Buchner funnel, washed with cold water then dried in oven at $70{ }^{\circ} \mathrm{C}$ for $5 \mathrm{~h}$ to give pale yellow solid $(5.8 \mathrm{~g}, 89 \%)$ : mp $255-257{ }^{\circ} \mathrm{C} ;{ }^{1} \mathrm{H} \mathrm{NMR}(600 \mathrm{MHz}$, DMSO-d 6 ) $\delta 9.95$ (bs, $1 \mathrm{H}, \mathrm{NH}), 7.7$ (d, J = 8.8 Hz, 2H, Ar), 7.57 (d, J = 8.8 Hz, 2H, Ar), $7.21(\mathrm{~d}, \mathrm{~J}=4.5 \mathrm{~Hz}, 1 \mathrm{H}, \mathrm{Ar}), 6.77$ $(\mathrm{d}, \mathrm{J}=4.5 \mathrm{~Hz}, 1 \mathrm{H}, \mathrm{Ar}), 5.82$ (bs, $1 \mathrm{H}, \mathrm{NH}), 4.14\left(\mathrm{q}, \mathrm{J}=7.1 \mathrm{~Hz}, 2 \mathrm{H}, \mathrm{CH}_{2}\right), 1.24\left(\mathrm{t}, \mathrm{J}=7.1 \mathrm{~Hz}, 3 \mathrm{H}, \mathrm{CH}_{3}\right) \mathrm{ppm}^{13} \mathrm{C} \mathrm{NMR}$ $\left(150.94 \mathrm{MHz}\right.$, DMSO-d $\left.{ }_{6}\right) \delta 168.61(\mathrm{Ar}) ; 153.32(\mathrm{C}=\mathrm{O}) ; 142.41(\mathrm{Ar}), 126.94(\mathrm{Ar}) ; 117.44(\mathrm{Ar}) ; 107.89(\mathrm{Ar}) ; 60.48\left(\underline{\mathrm{CH}}_{2}\right) ;$ $14.37\left(\mathrm{CH}_{3}\right)$, El-MS (m/z): 327 [M] ${ }^{+}$; Anal. Calcd for $\mathrm{C}_{12} \mathrm{H}_{13} \mathrm{~N}_{3} \mathrm{O}_{4} \mathrm{~S}_{2}: \mathrm{C}, 44.02 ; \mathrm{H}, 4.00 ; \mathrm{N}, 12.84 ;$ Found: $\mathrm{C}, 44.00 ; \mathrm{H}, 4.03$; N, $12.81 \%$.

\section{3- RESULTS AND DISCUSSION}

\subsection{OPEN CIRCUIT POTENTIAL MEASUREMENTS}

The open-circuit potential, $E_{o c}$ changes were measured against a standard saturated calomel electrode as reference electrode and mild steel of circular area of about $0.785 \mathrm{~cm}^{2}$ as working electrode and platinum wire as counter electrode were immersed in $0.1 \mathrm{MHCl}$ and the obtained results were listed in Figure (2). The potential of the mild steel electrode immersed in absence and presence of various concentrations of (TSPC) were measured. After half hour of immersion $E_{O C}$ displacement towards positive potentials was noticed. This increase seems to be related to the thickening of the protective film improving its corrosion protection ability was noticed in Table (1). This behavior suggests that the protective film formed from the inhibitor-metal complex is resistant the chemical dissolution of mild steel in $0.1 \mathrm{M} \mathrm{HCl} \mathrm{solutions} \mathrm{till} 400 \mathrm{ppm}$ and at 500ppm the protection behavior is decreased again.

Table (1) The Open Circuit Potential Values after half hour for mild steel samples immersion in $0.1 \mathrm{M} \mathrm{HCl}$ solution 


\begin{tabular}{|c|c|c|c|c|}
\hline Material & \multicolumn{4}{|c|}{ Mild steel } \\
\hline Concentrations & $\mathrm{Bl}$ & $200 \mathrm{ppm}$ & $400 \mathrm{ppm}$ & $500 \mathrm{ppm}$ \\
\hline Open Circuit Potential, Eoc $(\mathrm{mV})$ & -473 & -495 & -510 & -505 \\
\hline
\end{tabular}

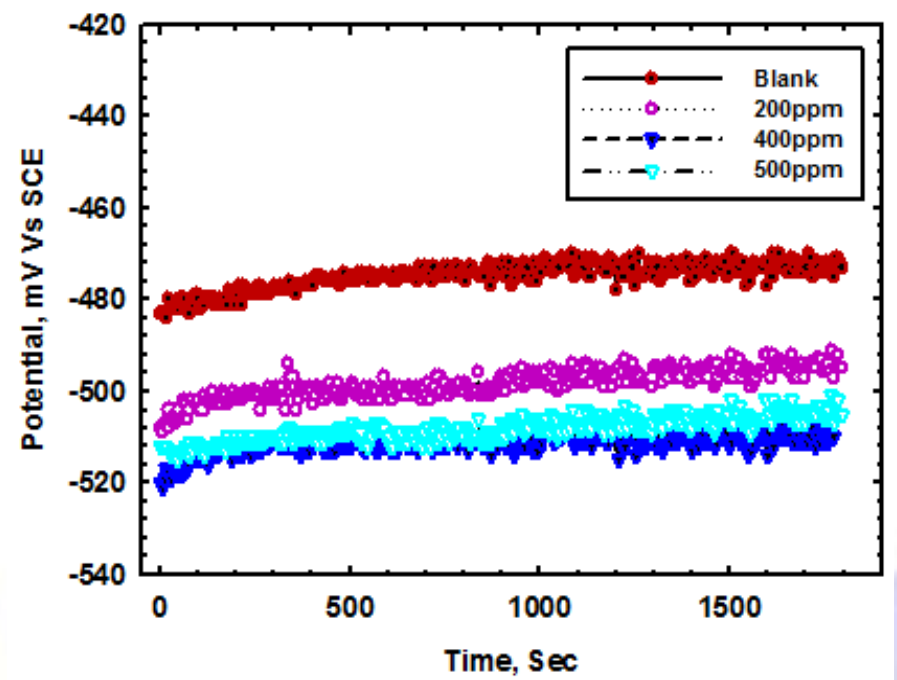

Figure (2) Open circuit potential Vs time for mild steel in $0.1 \mathrm{MHCl}$ at absence and the presence of the TSPC at various concentrations

\subsection{POTENTIODYNAMIC POLARIZATION MEASUREMENTS}

The potentiodynamic polarization curves for mild steel in $0.1 \mathrm{M} \mathrm{HCl}$ solutions in the absence and presence of various concentrations of TSPC were obtained and are shown in Figure (3). The Figure (3a) represents that the efficiency is directly proportional to the concentrations of inhibitor till 400ppm. By increasing the concentration the efficiency is retarded to lower value as mentioned in Figure $(3 \mathrm{~b})$. It is clearly noticed that $400 \mathrm{ppm}$ is the best dose, so it is selected as recommended dose, see Figure (3c).

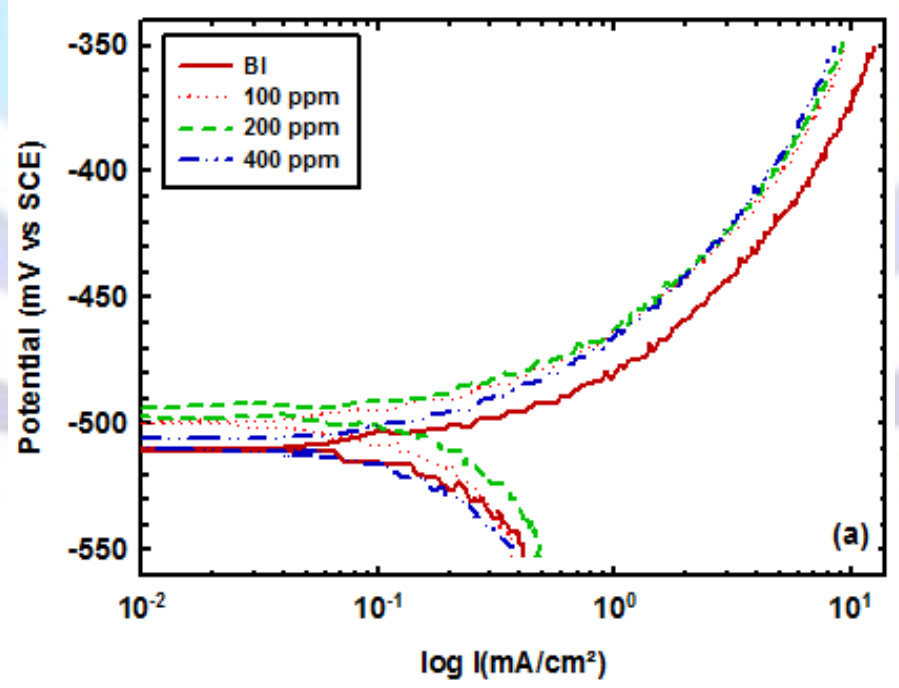



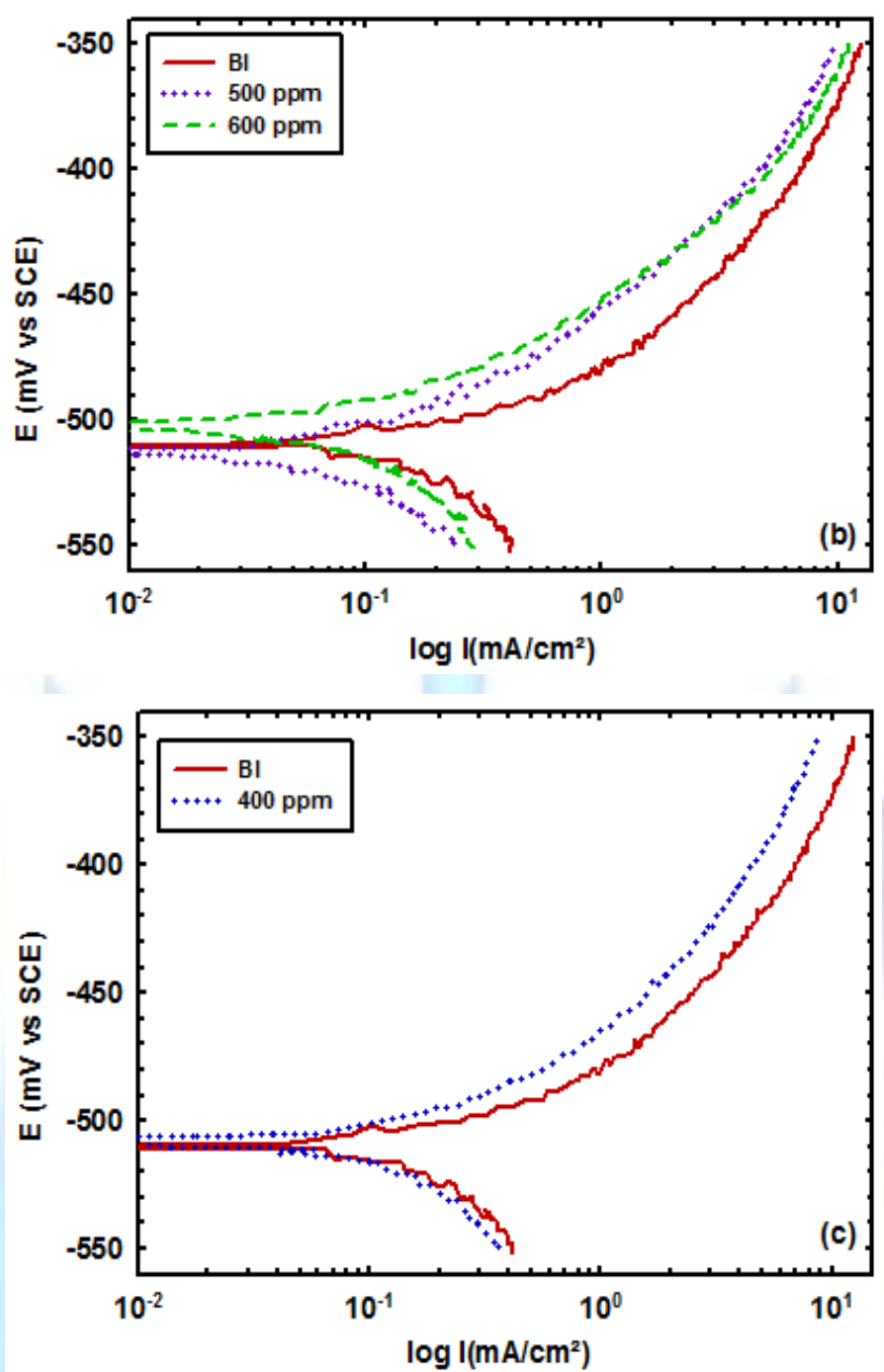

Figure (3) Potentiodynamic polarization curves for mild steel in $0.1 \mathrm{M} \mathrm{HCl}$ solution in absence and the presence of the TSPC at various concentrations (a) shows the directly proportional between concentration and efficiency till $400 \mathrm{ppm}$ (b) shows the inversely proportional relation of concentration and efficiency (c) shows the recommended dose

From the polarization curves at various concentrations, inhibition efficiencies (IE\%) of acid corrosion of mild steel in the presence of TSPC were obtained and are given in Figure (4). The inhibition Efficiency (IE \%) was calculated using the following relationship.

$$
\text { IE\% }=\frac{\text { Icorr }- \text { Icoo }(\mathrm{inh})}{\text { Icorr }} \times 100
$$

Where $I_{\text {corr }}$ and $I_{\text {corr(inh) }}$ represent the corrosion current density values without and with inhibitor, respectively. The inhibition efficiency is considered that the better expression for the corrosion resistance of TSPC which is clearly noticed that it increases with TSPC concentration till 400 ppm. 


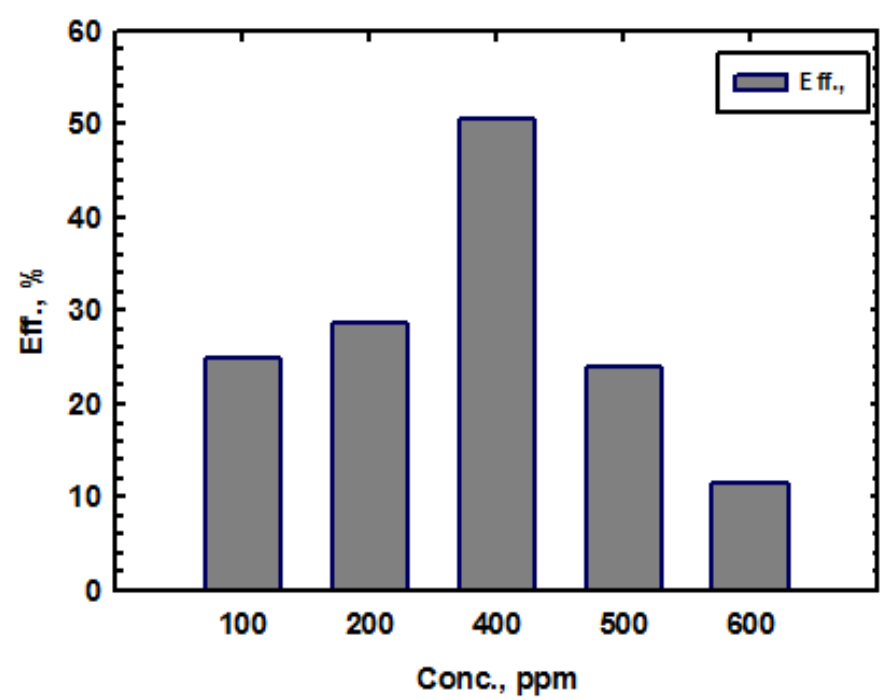

Figure (4) Concentration efficiency relationship from the gained data from polarization curves and it is clearly noticed that $400 \mathrm{ppm}$ is the best dose

\subsection{WEIGHT LOSS AND CORROSION RATES}

The corrosion rates of the mild steel in $0.1 \mathrm{M} \mathrm{HCl}$ solutions in the absence and presence of (TSPC) were determined. Figure (5) illustrates the variation of the corrosion rates of the mild steel in $0.1 \mathrm{M} \mathrm{HCl}$ with inhibitor concentration for an exposure time of 3 days. Figure (5) shows clearly that the (TSPC) retards the corrosion rate of the mild steel. The following equation is used to calculate the corrosion rate.

$$
\mathrm{CR}=\frac{\mathrm{K} \Delta \mathrm{W}}{\mathrm{DAT}}
$$

Where $\mathrm{CR}$ is the corrosion rate, $\Delta \mathrm{W}$ is the weight loss in $\mathrm{mg} ; \mathrm{D}$ is the density of the steel $\left(7.86 \mathrm{~g} / \mathrm{cm}^{3}\right) ; \mathrm{A}$ is the exposed area of the coupon $\left(22.5 \mathrm{~cm}^{2}\right)$; $\mathrm{T}$ is the immersion time $(20 \mathrm{hrs}) ; \mathrm{K}=3.45 \times 10^{6}$ in case of $\mathrm{CR}$ in mpy. Moreover, it can be seen from Figure (4) that the corrosion rate decreases with increase in the concentration of the inhibitor [20-21]. It is also clearly noticed that at the dose of $500 \mathrm{ppm}$ the corrosion rate start to increase again and the obtained results were agreed with the all used tools for investigation of the corrosion control of (TSPC). The calculated efficiencies from the weight loss data are presented in Figure (6). The highest efficiency is obtained at the dose of 400ppm and by increasing the concentration the efficiency is decreased due to the degradation of the formed protective film because of the agglomeration of the organic molecule on the metal surface.

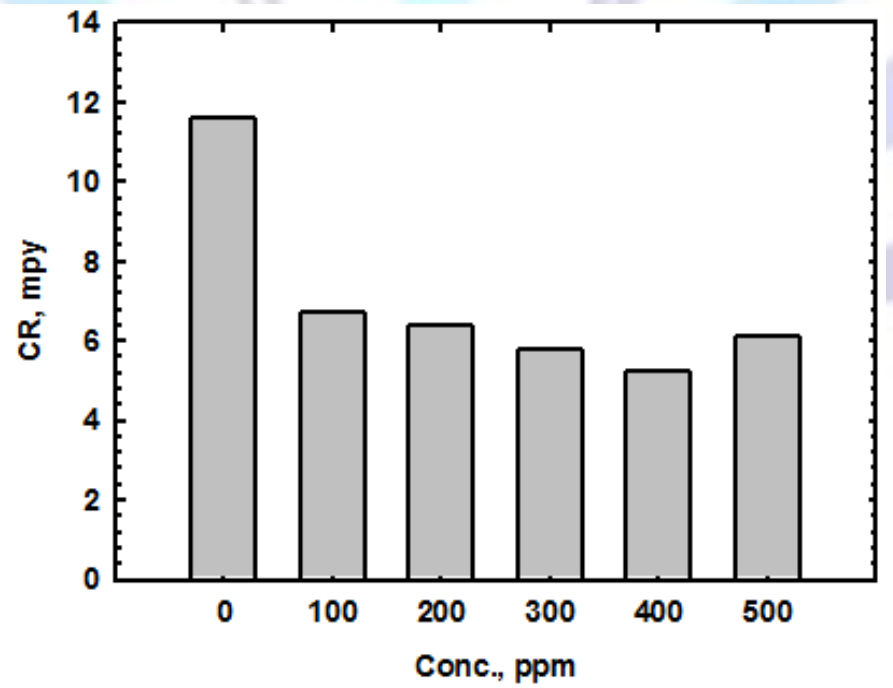

Figure (5) Corrosion rate of $0.1 \mathrm{M} \mathrm{HCl}$ on mild steel in the absence and the presence of (TSPC) at various concentrations after 20 hours of immersion 


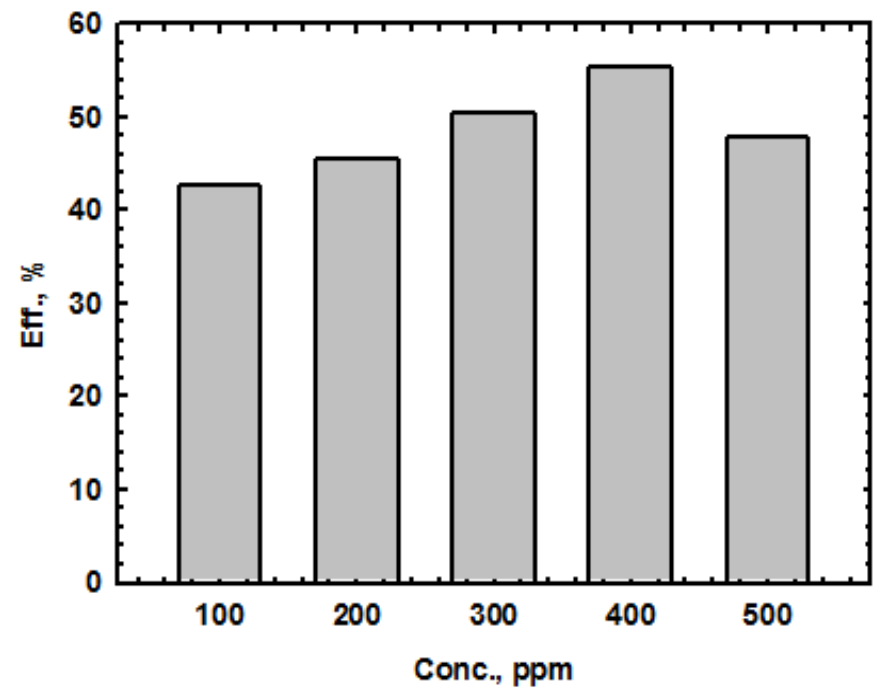

Figure (6) Concentration efficiency relationship from the gained data from weight loss after 20 hrs and it is clearly noticed that $400 \mathrm{ppm}$ is the best dose

\subsection{ELECTROCHEMICAL IMPEDANCE SPECTROSCOPY}

The EIS tool was also used as a complementary study to investigate the corrosion resistance of (TSPC) on the mild steel in acidic media. The obtained impedance data, at $E_{O C}$, with the mild steel immersed for 30 min are presented as Nyquist plot are plots in Figure (7). From the gained data in Table (2), it is seems that the values of $R_{p}$ increases with increase the concentration of (TSPC) which prove that the possibility of forming passive film. The impedance increases with the increase of (TSPC) concentration which is a typical response for the all used tools and corresponds to the obtained results. We can also notice that the solution resistance, $R_{u}$ which gives the same behavior.

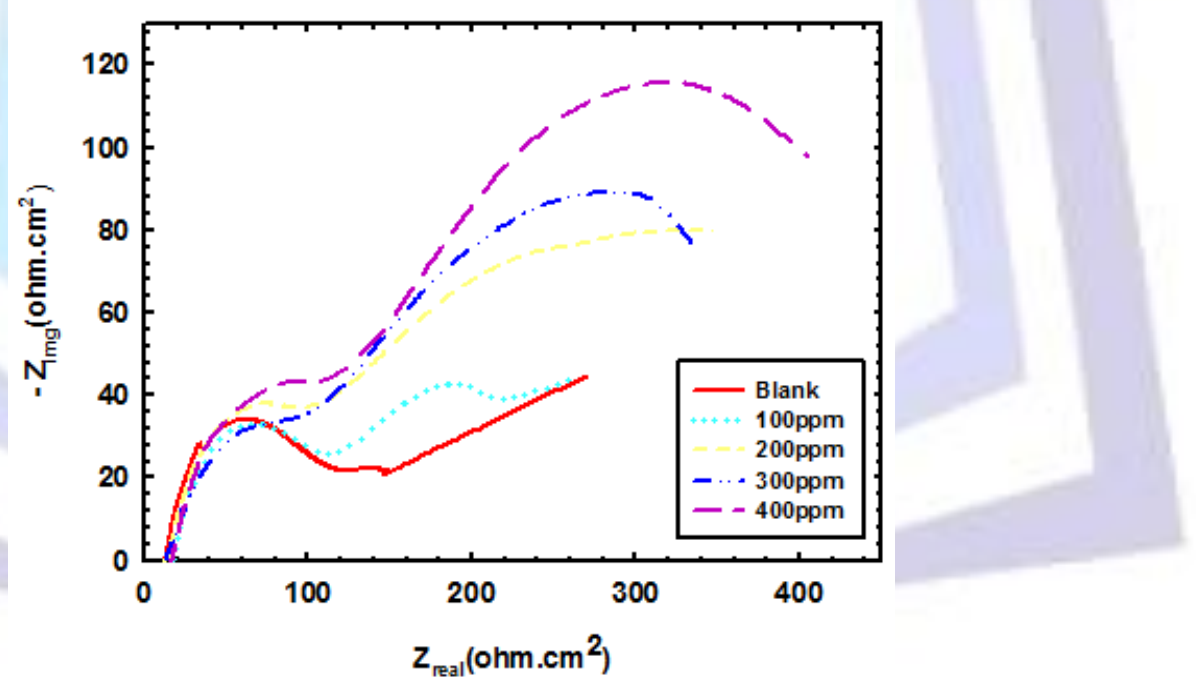

Figure (7) Nyquist plots curves for mild steel in different concentrations of TSPC

Table (2) Effect of different concentrations of TSPC on the polarization resistance $\left(R_{p}\right)$ and the double layer capacitance (C) of the mild steel/electrolyte interfaces in $0.1 \mathrm{M} \mathrm{HCl}$.

\begin{tabular}{|l|c|c|c|c|c|}
\hline $\begin{array}{l}\text { EIS } \\
\text { Parameters }\end{array}$ & Blank & $100 \mathrm{ppm}$ & $200 \mathrm{ppm}$ & $300 \mathrm{ppm}$ & $400 \mathrm{ppm}$ \\
\hline $\mathrm{R}_{\mathrm{p}}$ Ohms & 269.8 & 292.0 & 326.7 & 335.6 & 405.3 \\
\hline $\mathrm{R}_{\mathrm{u}}$ Ohms & 3.11 & 3.40 & 3.56 & 3.60 & 4.09 \\
\hline $\mathrm{C}_{\mathrm{f}} \mathrm{F}$ & $3.69 \mathrm{E}-05$ & $4.91 \mathrm{E}-05$ & $2.53 \mathrm{E}-05$ & $2,26 \mathrm{E}-05$ & $2.41 \mathrm{E}-05$ \\
\hline
\end{tabular}




\subsection{ADSORPTION ISOTHERMS}

It is well known that the degree of surface coverage $(\theta)$ is connected with inhibition efficiency of a direct relationship and this relationship is presented in the next equations $(3,4)$.

$$
\begin{aligned}
& \text { IE \% }=\left[\mathrm{W}_{\mathrm{BI}}-\mathrm{W}_{\mathrm{inh}} / \mathrm{W}_{\mathrm{BI}}\right] \times 100 \\
& \theta=\left[\mathrm{W}_{\mathrm{BI}}-\mathrm{W}_{\mathrm{inh}} / \mathrm{W}_{\mathrm{BI}}\right]
\end{aligned}
$$

The obtained data from weight loss measurements were adapted to determine the fit to some well-known adsorption isotherms including the Langmuir and Temkin, isotherms. The gained experimental adsorption data fit the Langmuir and Temkin isotherm. The linear fit for Langmuir and Temkin isotherm is illustrated for (TSPC) on mild steel at room temperature of about 25 $\mathrm{C}$ in Figure $(7,8)$ respectively. Figure (7) shows Langmuir isotherm which give the relation between $(C)$ and $(C / \theta)$ according to the following relation cited in eq.(5). Figure (8) shows the Temkin isotherm which gives the relation between $\theta$ and $\ln C$ as shown in eq. (6).

$$
C / \theta=1 / k+C
$$

Where $\theta$ the degree of surface coverage, $\mathrm{K}$ is the equilibrium constant of the adsorption process and $\mathrm{C}$ is the molar inhibitor concentration.

$$
\theta=(1 / f) \ln k_{\text {ads }} C
$$

Where $\theta$ is a linear function of $\operatorname{In} C$ and $f$ is a factor that clearly takes in account adsorbent-adsorbates interactions which considers the fact that the adsorption heat of all molecules in the layer decreases with coverage due to the adsorbateadsorbent interaction [24,25]. The adsorption parameters of the linear fits intercept the $y$-axis $(C / \theta)$ or the $x$-axis $(C)$ and the slopes, which corroborates to the isotherm prediction are listed in Table (3). It is well know that the Langmuir isotherm is concerned with qualitative describing the chemisorptions and physisorption processes so it is subjected to a number of modifications including the molecular interaction term [26]. The linear relation of $\theta$ versus $\ln C$ is well agreed with the Temkin equation this is clearly proved by the obtained parameters of Temkin isotherm which presented in table (3). The equation (7) is used to calculate the standard free energy of adsorption $\Delta \mathrm{G}^{\circ}$ ads.

$$
\mathrm{K}=\frac{1}{55.5} \exp \left(\frac{-\Delta \mathrm{G}}{\mathrm{RT}}\right)
$$

The $\Delta \mathrm{G}^{\circ}$ ads values obtained from the Langmuir and Temkin isotherm at room temperature are -3.362 and $-12.383 \mathrm{~kJ} / \mathrm{mol}$ respectively, which indicates that the nature of adsorption is physisorption. The obtained negative values of $\Delta \mathrm{G}^{\circ}$ ads indicate spontaneity of the adsorption process. The $\Delta \mathrm{G}^{\circ}$ ads values proved that there are electrostatic interactions between organic molecules and charged metal surface, which also proved that the kind of adsorption is physisorption.

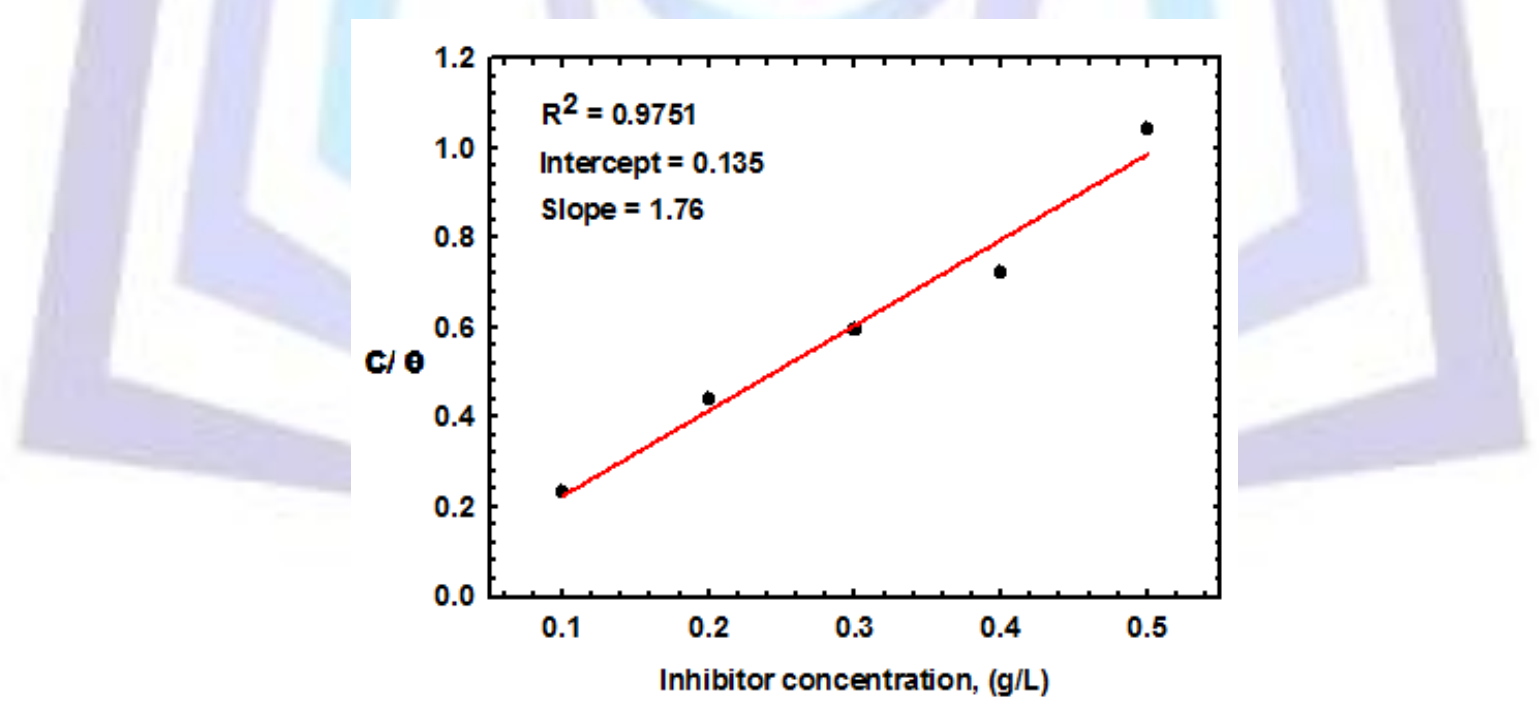

Figure (7) Langmuir parameters of the adsorption isotherm for the (TSPC) on the mild steel surface 


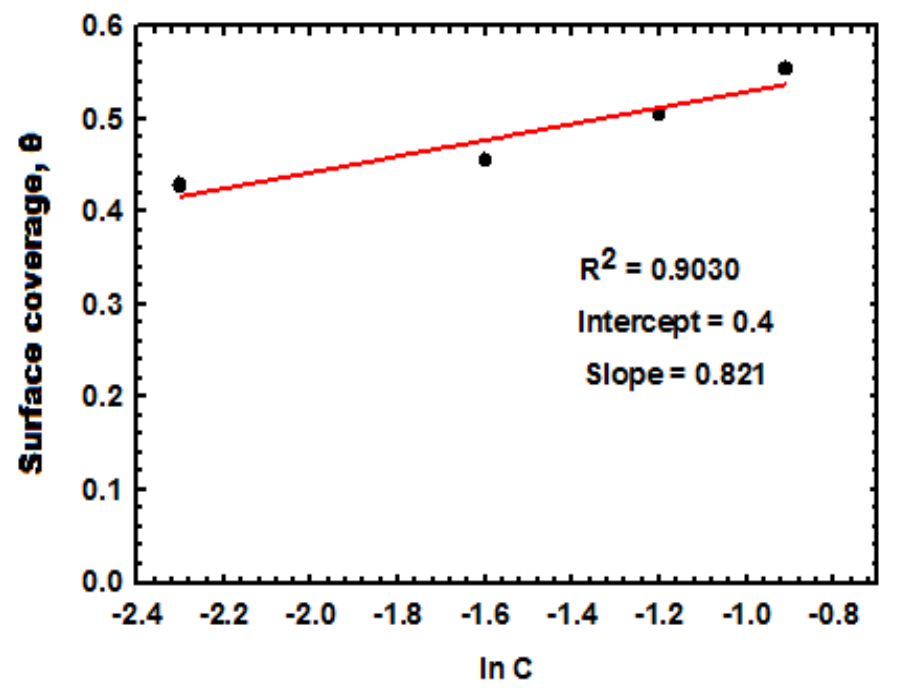

Figure (8) Temkin isotherm of the adsorption isotherm for the (TSPC) on the mild steel surface

Table (3) The obtained parameters of adsorption isotherm from the weight loss corrosion data for mild steel in $0.1 \mathrm{M} \mathrm{HCl}$ containing (TSPC)

\begin{tabular}{|c|c|c|c|c|c|}
\hline Isotherm & Intercept & Slope & $k$ & $R^{2}$ & $\Delta G_{\text {ads }}(\mathrm{kJmol})$ \\
\hline \multicolumn{7}{|c|}{ Langmuir } \\
\hline 298 & 0.135 & 1.76 & 0.568 & 0.9751 & -3.362 \\
\hline \multicolumn{7}{|c|}{ Temkin } & 1.22 & 0.9030 & -12.383 \\
\hline
\end{tabular}

\subsection{HEALTH IMPACT OF (TSPC)}

The (TSPC) is considered as one of the sulfathiazole and sulfamethylthiazole derivatives and it is well known that these compounds are used to struggle some bacterial diseases in human bodies so it is approved as safe compounds [27-30]. The used dose in human system started from 1.25 to $20 \mathrm{mg}$ percent and these used doses is very high compared with the used dose in our present work $4.0 \mathrm{mg}$ percent. Whilst the inhibition efficiency is in moderate value but it is recommended for use because of its safety and in the same time it is easily prepared.

\section{ACKNOWLEDGEMENTS}

We gratefully acknowledge the support and help from Dr. Hassan Amer Abdel-Zhaher and Dr. Andreas Hofinger regarding ${ }^{1} \mathrm{H}$ and ${ }^{13} \mathrm{C}$ NMR data acquisition.

\section{CONCLUSIONS}

The corrosion behavior of mild steel in $0.1 \mathrm{MHCl}$ is evaluated in absence and presence of synthesized (TSPC) as a corrosion inhibitor by using electrochemical techniques and weight loss measurements. The obtained data from the all used techniques proved that the corrosion rate and its comparable efficiencies are consistent. The (TSPC) is considered as moderate corrosion inhibitor for mild steel $0.1 \mathrm{MHCl}$ solutions. The obtained complex between the inhibitor and steel surface is give good results till $400 \mathrm{ppm}$ but over this dose the efficiency is decreases due to the agglomeration of the organic molecule on the metal surface. The EIS results show that the mild steel exhibit passivity in presence of (TSPC), which is clearly noticed from $R_{p}$ values.

The inhibition efficiency increases with the inhibitor concentration, and the maximum of $55.5 \%$ was obtained at the concentration of $0.4 \mathrm{mg} / \mathrm{l}$. The adsorption of mild steel surface obeys the Langmuir adsorption isotherm and is a spontaneous, exothermic process. The weight loss measurements were carried out without and with (TCPS) and the corrosion rate of steel in $0.1 \mathrm{MHCl}$ solution act as a function of immersion time $20 \mathrm{hrs}$ of exposure, which indicates that presence of adsorptive film over the mild steel surface.

The (TSPC) is considered as one of the green chemicals, and recently it is well known that the trend in all over the world to the use of environmentally friendly and safe chemicals instead of hazardous compounds on the human's bodies and this is one of the most important goals of our research. 


\section{REFERENCES}

[1] Schmitt, G., (1984). Application of inhibitors for acid media. Brit. Corr. J., 19: 165-176.

[2] Tebbji, K., I. Bouabdellah, A. Aouniti, B. Hammouti, H. Oudda, M. Benkaddour, and A. Ramdani, 2007. Nbenzyl- N, Nbis[(3,5-dimethyl-1H-pyrazol-1-yl)methyl]amine as corrosion inhibitor of steel in $1 \mathrm{M} \mathrm{HCl}$. Mat. Lett., 61: 799-804.

[3] Bentiss, F., F. Gassama, D. Barbry, L. Gengembre, H. Vezin, M. Lagrenée and M. Traisnel, (2006). Enhanced corrosion resistance of mild steel in molar hydrochloric acid solution by 1,4-bis(2-pyridyl)-5Hpyridazino[4,5-b]indole: Electrochemical, theoretical and XPS studies. Appl. Surf. Sci., 252: 2684-2691.

[4] Prabhu, R. A., A. V. Shanbhag and T. V. Venkatesha, (2007). Influence of tramadol [2-[(dimethylamino) methyl]-1- (3methoxyphenyl) cyclohexanol hydrate] on corrosion inhibition of mild steel in acidic media. J. of Appl. Electrochem., 37: 491-497.

[5] Avci, G., (2008). Corrosion inhibition of indole-3-acetic acid on mild steel in $0.5 \mathrm{M} \mathrm{HCl}$. Colloids and Surfaces A: Physicochemical Engineering Aspects, 317: 730-736.

[6] Niketan S. Patel, Divyesh K. Patel, Premlata Kumari and Girishkumar N. Mehta. (2009). Influence of Nbenzylimidazole on Mild Steel Corrosion Inhibition in Hydrochloric Acid:Adv. in Nat. Appl. Sci., 3(3):419-423.

[7] Tamilselvi, S.; Raman, V.; Rajendran, N. (2003). Corrosion inhibition of mild steel by benzotriazol derivatives in acidic medium. J. Appl. Electrochem. 33, 1175-1182.

[8] Antonijevic, M. M.; Bogdanovic, G. D.; Radovanovic, M. B.; Petrovic, M. B.; Stamenkovic, A. T. (2009). Influence of pH and Chloride Ions on Electrochemical Behavior of Brass in Alkaline Solution. Int. J. Electrochem. Sci., 4, 654-661.

[9] Bentiss, F.; Lebrini, M.; Vezin, H.; Lagrenee, M. (2004). Experimental and theoretical study of 3-pyridyl-substituted 1, 2 , 4-thiadiazole and 1, 3, 4-thiadiazole as corrosion inhibitors of mild steel in acidic media. Mat. Chem. Phys., 87, 18-23.

[10] Bentis F, Transnel M, Chaibi N, Mernari B, Vezin H, Lagrenee M. (2002). 2, 5- Bis(nmethoxyphenyl)- 1, 3, 4oxadiazoles used as corrosion inhibitors efficiency and chemical structure. Corr. Sci., 44: 2271-2289.

[11] Trabanelli, G., (1987). Corrosion inhibitors: Corrosion mechanisms. USA: Marcel Dekker.

[12] K.C. Emregul, O. Atakol. (2003). Corrosion inhibition of mild steel with Schiff base compounds in $1 \mathrm{M} \mathrm{HCl}$, Mat. Chem. Phys. 82, 188-193.

[13] M. Behpour, S.M. Ghoreishi, M. Salavati-Niasari, B. Ebrahimi, (2008). Evaluating two new synthesized S-N Schiff bases on the corrosion of copper in 15\% hydrochloric acid, Mat. Chem. Phys. 107, 153-157.

[14] Muralidharan, S., R. Chandrasekar and S. V. K. lyer, (2000). Effect of piperidones on hydrogen permeation and corrosion inhibition of mild steel in acidic media. Proceedings of the Indian Academy of Sciences (Chemical Sciences), 112: $127-136$.

[15] Yan, Y., W. Li, L. Cai and B. Hou, (2008). Electrochemical and quantum chemical study of purines as corrosion inhibitors for mild steel in $1 \mathrm{M} \mathrm{HCl}$ solution. Electrochem. Acta, 53: 5953-5960.

[16] Stewart, J. (1922). J. Chem. Soc., 121, 2558.

[17] Furniss, B. S.; Hannaford, A. J.; Rogers, V.; Smith, P. W. G.; Tatchell, A. R. (1979). Vogel's Textbook of Practical Organic Chemistry.; Longmann: London.

[18] Walter, F. (1939). J. Am. Chem. Soc., 61, 2032.

[19] Leitch, L. C.; Baker, B. E.; Brickman, L. (1945). Can. J. Res. Sec. B: Chem. Sci., 23, 139.

[20] Emeka E. Oguzie, (2007). "Corrosion inhibition of aluminum in acidic and alkaline media by Sansevieria trifasciata extract". Corr. Sci., vol.49, pp.1527-1539.

[21] E. Oguzie, G. Onuoha, E. Ejike. (2007). "Effect of Gongronema latifolium extract on aluminium corrosion in acidic and alkaline media", Pigment Resin Technology, vol.36, no.1, pp.44-49.

[22] H. Ashassi-Sorkhabi, D. Seifzadeh, M.G. Hosseini. (2008). "EN, EIS and polarization studies to evaluate the inhibition effect of 3H-phenothiazin-3-one, 7-dimethylamin on mild steel corrosion in $1 \mathrm{M} \mathrm{HCl}$ solution", Corr. Sci., vol.50, pp.3363-3370.

[23] S. Martinez. (2003). "Inhibitory mechanism of mimosa tannin using molecular modeling and substitutional adsorption isotherms", Mat. Chem. and Phys., vol.77, no.1, pp.97-102.

[24] Regina Fuchs-Godec, Gregor Žerjav, (2009)."Inhibition Properties of Triton-X-100 on Ferritic Stainless Steel in Sulphuric Acid at Increasing Temperature", Acta Chimica Slovenica, vol.56, no.1, pp.78-85.

[25] Lebe A. Nnanna, Israel O. Owate, Onyinyechi C. Nwadiuko, Nneka D. Ekekwe, Wisdom J. Oji. (2013). "Adsorption and Corrosion Inhibtion of Gnetum Africana Leaves Extract on Carbon Steel", International Journal of Materials and Chemistry, 3(1): 10-16. 
[26] Ruth Villamil, Paola Corio, Silvia Agostinho, Joel Rubim, (1999). "Effect of sodium dodecylsulfate on copper corrosion in sulfuric acid media in the absence and presence of benzotriazole", Journal of Electroanalytical Chemistry, vol.472, no.2, pp.112-119.

[27] R. D. Muir, V. J. Shamleffer and L. R. Jones. (1942). Studies Pertaining to the Antibacterial Activity of Sulfathiazole and its methyl derivative. J. Bacteriol., 44, (1), 95-110.

[28] M. G. Sevag, Jane Henry and Ruth A. Richardson. (1945). Studies on the action of Sulfonamides on the Respiration and Growth of Bacteria: A. Factors Controlling the Inhibition by Sulfonamides of Carboxylases. II. Antagonism Between p-Aminobenzoic Acid and Sulfathiazole. J. Bacteriol., 49 (1):71-77.

[29] El-Sayed M. Sherif, Adel Taha Abbas, D. Gopi, A. M. El-Shamy. (2014). "Corrosion and Corrosion Inhibition of High Strength Low Alloy Steel in 2.0 M Sulfuric Acid Solutions by 3-Amino-1, 2, 3-triazole as a Corrosion Inhibitor". Journal of Chemistry Volume 2014, Article ID 538794, 8 pages.

[30] El-Sayed M. Sherif, Adel Taha Abbas, Hossam Halfa and A. M. El-Shamy. (2015.) "Corrosion of High Strength Steel in Concentrated Sulfuric Acid Pickling Solutions and Its Inhibition by 3-Amino-5-mercapto-1,2,3-triazole". Int. J. Electrochem. Sci., (10), p 1777 - 1791.

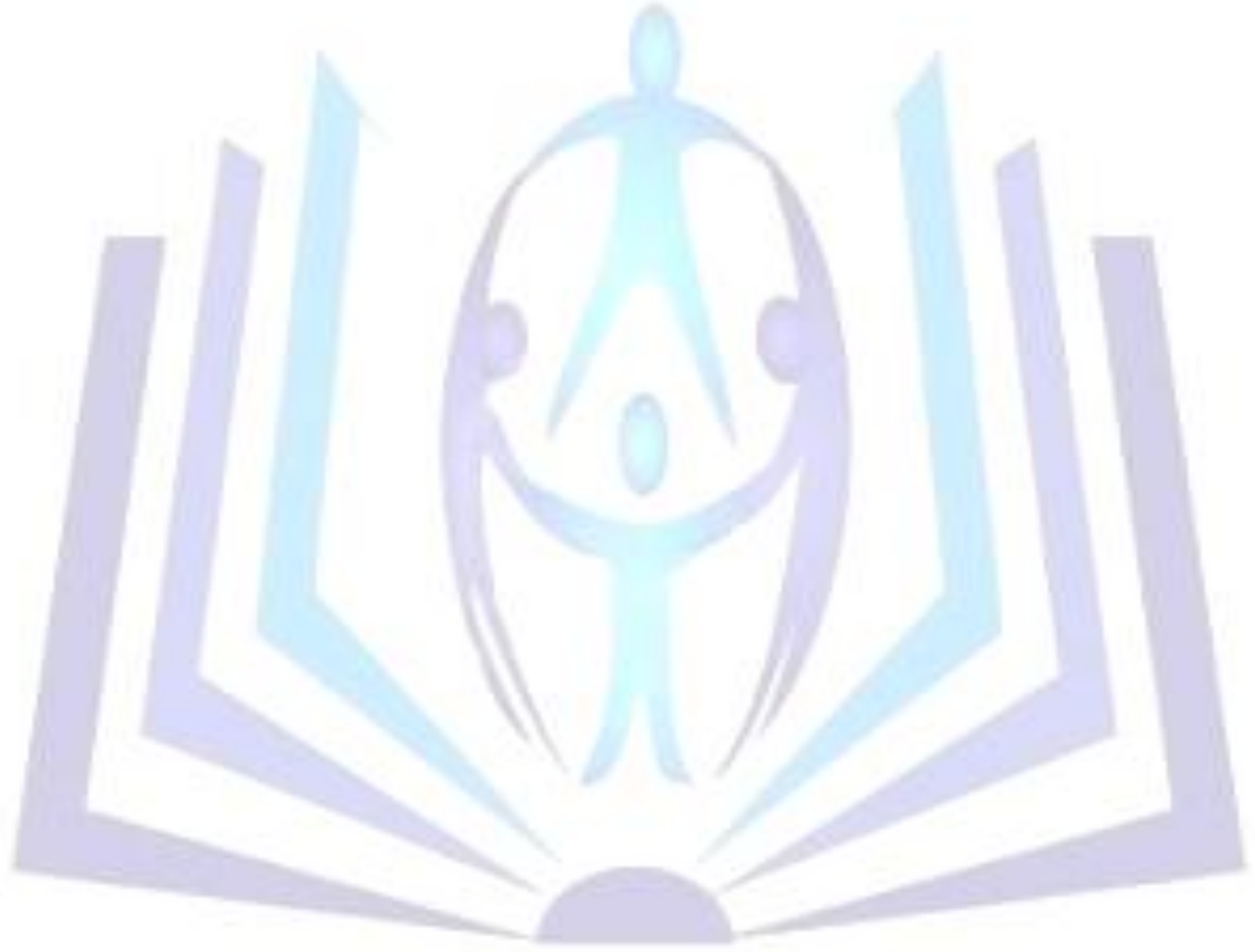

